\title{
Sediment characteristics and accumulation rates in constructed ponds
}

\author{
A.S. Brainard and G.W. Fairchild
}

\begin{abstract}
Pond densities have increased rapidly during recent decades within the Brandywine Watershed, southeastern Pennsylvania. Sediments trapped by these ponds are prevented from impairing stream networks, but also reduce pond longevity and increase management costs. This study investigates spatial variation of sediment characteristics within ponds as a function of pond morphology and related variation in sediment accumulation rates among ponds to differences in pond size and watershed attributes. Increasing distance from shore was accompanied by decreasing sediment dry bulk density, decreasing percentage of sand, and increasing organic content; pond area-specific sediment accumulation rates and rates of area-specific organic matter sequestration declined with increasing pond size and were significantly higher among ponds with stream inflows. Sediment delivery rates per unit catchment area declined with increasing watershed size. Because excessive sediment loading is perhaps the most important cause of stream impairment in many regions, the interception of sediments by ponds within stream networks may be of critical importance to downstream water quality. Results of this study also provide evidence that small, constructed ponds can be important tools for estimating sediment yield and stream-borne sediment transport within small catchments.
\end{abstract}

Key words: inflow—organic matter—pond—sediment—watershed

\begin{abstract}
Constructed ponds, built for varying purposes and at different times in the past, are proliferating in many regions, yet their role in trapping sediments remains poorly understood. Although no ecologically based criteria definitively separate ponds from lakes and reservoirs, constructed ponds are generally recognized as small-Biggs et al. (2005) have suggested surface areas between $1 \mathrm{~m}^{2}$ and $2 \mathrm{ha}\left(10.8 \mathrm{ft}^{2}\right.$ and $\left.4.9 \mathrm{ac}\right)$ in area as a defining feature - and shallow, with sufficient light penetration to support widespread benthic primary production (Søndergaard et al. 2005). Ponds often elevate stream temperatures during warmer months (Maxted et al. 2005), alter nutrient chemistry (Rausch and Schreiber 1981; Fairchild and Velinksy 2006), and sometimes replace other land features of ecological value (Tiner 1989). Ponds also interfere with hydrologic connectivity and the movement of stream organisms (Santucci et al. 2005), although Jackson and Pringle (2010) have argued that such impoundments can sometimes lead to enhanced protection of threatened species.
\end{abstract}

One generally positive impact of constructed ponds is their role in retaining sediments that would otherwise impair stream networks. Sediment retention influences pond longevity and the costs of pond management and is one of the most important descriptive features of an impoundment (Heinemann 1981). Sediment characteristics and distribution within ponds also influence aquatic biodiversity. However, perhaps because of their small size and relatively recent proliferation (Smith et al. 2002; Downing et al. 2006; Downing 2010), constructed ponds have received less attention than larger lakes and reservoirs in terms of their sediment properties and burial rates.

Constructed ponds usually have catchments that are commensurately smaller than those of larger water bodies. As catchment size increases, sediment yield per unit catchment area typically declines, although the relationship may vary considerably depending on topographic features and land use (Renwick et al. 2005; de Vente et al. 2007). As a result, a large proportion of the sediment entering a pond from its catchment may originate near the pond itself (HayesBohanan 1989).

Sediments first arrive at the pond perimeter either as suspended stream inputs or as part of overland runoff. Bank erosion likewise generates sediment at the pond margin. Larger ponds usually have greater ratios of surface area/perimeter than smaller ponds (Fairchild et al. 2005) and are thus likely to receive less sediment per unit pond area (Downing et al. 2008). In addition, larger ponds often have relatively larger watersheds, with more drainage area potentially delivering sediment into these larger basins.

Once sediments have entered a pond, subsequent distribution largely depends on wind-generated currents and particle characteristics (especially size and density). Sand typically is deposited relatively rapidly and is thus expected to predominate near the point of entry, whereas smaller silts and clays experience greater persistence within the water column and often reach deeper water further from shore. Plankton particles generated within the pond itself should settle more slowly than denser sand grains and accumulate primarily in deeper water. Sediment dry bulk density ( $\mathrm{dBD})$, nutrient content, and organic matter (OM) are often correlated with sediment particle size.

Sediment particle size distribution, particulate $\mathrm{OM}$, and nutrient content are known to influence meiofaunal invertebrate richness and abundance (Bert et al. 2007) and the distribution of rooted macrophytes (Xie et al. 2005). Macrophytes not only create habitat and resources for algal biofilms, invertebrates, and fish (DeClerck et al. 2005) but also reduce water movement, thereby increasing sediment deposition (Madsen et al. 2001). In effect, much of the pond community (Oertli et al. 2005) may depend on within-pond variation in sediment characteristics.

The estimation of annual sediment burial rate, when calculated for a time interval of several decades since a known date of pond construction, integrates short-term impacts of storm events that introduce large quantities of sediment (Mielke 1985), disturbance

Andrew S. Brainard was a graduate student at West Chester University and is now a graduate student at SUNY College of Environmental Science and Forestry in Syracuse, New York. G. Winfield Fairchild is a professor in the Department of Biology, West Chester University, West Chester, Pennsylvania. 
associated with the construction process (e.g., initial bank erosion), and longer-term changes in land use within the watershed. As sediments fill in the original pond basin, particles brought into the pond or resuspended during storm events are increasingly lost via the outfall, such that the trap efficiency of ponds in retaining sediment inputs is reduced (Rausch and Heinemann 1975; Verstraeten and Poesen 2001). Calculated rates of annual sediment burial may thus vary over time and among ponds of varying age. The calculation of burial rates is nonetheless needed by pond owners to predict pond lifespan and probable management costs and by land managers concerned with the degree to which ponds sequester sediments within stream-based watersheds.

Here, we describe the sediment characteristics and accumulation rates in 10 ponds of known age in the Brandywine Watershed of southeast Pennsylvania. Cores were analyzed for sediment characteristics, and accumulated sediment volume was determined by additional probing of sediment depth. First, we related within-pond variation in three sediment characteristics- $\mathrm{dBD}$, sand (\% sand), and OM - in relation to core location; we hypothesized that sediments near shore would contain higher $\mathrm{dBD}$ and lower OM content than deeper sediments further from shore. We expected that sand content would decrease with increasing distance from shore.

Second, we related differences in annual sediment accumulation rates among ponds (as sediment volume and OM burial) to pond area, watershed size, and the presence or absence of a stream inflow. We hypothesized that small ponds would experience greater rates of total sediment and OM accumulation per unit surface area than larger ponds. Sediment inputs are strongly dependent on shoreline extent and processes, whereas storage is distributed in proportion to area. Thus, as the ratio of area to perimeter increases with overall size in ponds of simple geometric shape (see above), accumulation rates are expected to decrease. We further hypothesized that ponds with stream inflows would accumulate sediments more rapidly than ponds without inflows. Stream inflows are widely understood to be conduits of sediment movement, but to our knowledge, the effect of stream inflow on sediment accumulation in ponds has not been documented. Finally, we hypothesized that larger

\section{Figure 1}

Map of the Brandywine Creek Watershed, southeastern Pennsylvania and northern Delaware, showing the location of the 10 ponds studied (black circles), and population density (per $\mathrm{km}^{2}$ ). Light grey indicates population density $<100 \mathrm{~km}^{-2}$, medium grey represents intermediate population density $\left(100 \mathrm{~km}^{-2}<\right.$ population density $\left.<1,000 \mathrm{~km}^{-2}\right)$, and dark grey indicates population density greater than $1,000 \mathrm{~km}^{-2}$.

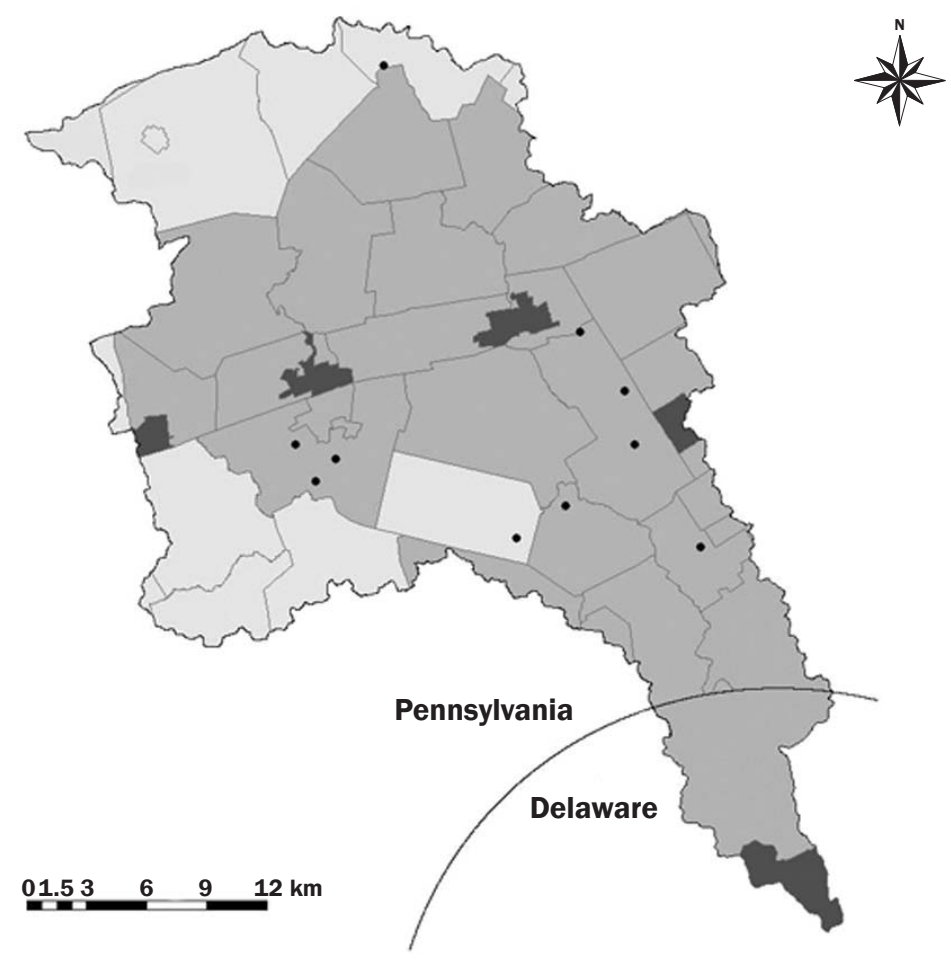

watersheds would contribute less sediment per unit watershed area, owing to the interception of sediments in swales and rills (de Vente et al. 2007).

\section{Materials and Methods}

Study Area. The Brandywine Creek Watershed encompasses approximately 840 $\mathrm{km}^{2}$ (324 $\left.\mathrm{mi}^{2}\right)$ of rolling piedmont in southeastern Pennsylvania and northern Delaware (figure 1). Two cities (Wilmington, Delaware and Coatesville, Pennsylvania) and several smaller Pennsylvania boroughs (West Chester, Downingtown, and Parkesburg) currently form pockets of particularly high population density. Much of the eastern and southern portion of the watershed is suburban with abundant residential land, whereas many of the more western and northern townships remain relatively rural. Population density has increased 6-fold, and pond abundances approximately 18 -fold, during the past 7 decades (one of us [G.W. Fairchild] has compiled a database of locations, areas, and approximate construction dates for ponds in the watershed). In-line impoundments, constructed primarily as sources of stream hydropower during the 1700 s and 1800 s (Walter and Merritts 2008), have since been increasingly replaced by ponds that receive less surface inflow.

Ten ponds were selected for study based on (a) small size (area $<1$ ha $[<2.5 \mathrm{ac}]$, consistent with $96.8 \%$ of 1,815 water bodies identified within the Brandywine drainage system in 2005), (b) the presence or absence of a stream inflow (5 ponds received water from first-order streams, and 5 had no stream inflows), (c) a known construction date, and (d) a known management history (following consultation with the owners, ponds that had at any time been dredged, changed in size, or drained were excluded from the study).

Field Work and Geographic Information System Analysis. Each pond was sampled on a single day during May 2009 to July 2009, avoiding days that immediately followed rain events. Water depth and the depth of accumulated sediment were first determined at 33 to 46 locations (depending on pond area and shape) using a small two-person pram. Locations were visually positioned to form 
a grid of regularly spaced measurements within each pond and recorded using a Trimble Pro-XR Global Positioning System (GPS) unit, with submeter accuracy. At each location, an extensible metal rod with a circular disc attached at one end was first lowered manually until the disk reached the current sediment surface and then inverted and pushed to the original pond bottom. The sediments were easily penetrated, and contact with the compact parent soil beneath the accumulated sediment was apparent; replicate measurements were performed on infrequent occasions when initial depth estimates were uncertain. Sediment depth was calculated as the difference between the current and original pond depths (e.g., Newman et al. 2006). The GPS data were later exported to ArcGIS v. 9.3 for determination of current and original water volumes, estimation of total sediment volume (by difference), and preparation of bathymetric maps using ArcView 3D Analyst.

The pond perimeter was recorded by attaching the GPS sensor to the end of a long boom and rowing around the edge of the pond with the sensor positioned over the shoreline. The GPS-produced polygon was exported to ArcGIS in order to calculate pond area. GPS points were edited as necessary, by comparison of the polygon with aerial photos, to compensate for the occasional presence of snags and overhanging branches.

Catchment area for each pond was computed using the ArcGIS extension Spatial Analyst, utilizing $30 \mathrm{~m}$ (98 ft) digital elevation models. The raster-generated watersheds were converted to polygons and edited based on comparison with additional datalayers

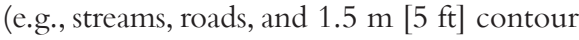
lines) to improve estimation accuracy.

Cores were obtained at 10 GPS-indexed locations within each pond, positioned visually in a grid pattern to represent the full range of variation in depth and distance from shore, using a handheld Wildco corer with a clear plastic inner sleeve (length $51 \mathrm{~cm}$ [20 in], diameter $4.7 \mathrm{~cm}$ [1.9 in]). Following retrieval of each core to the pram, a plunger was slowly pushed upward inside the inner sleeve, first allowing the overlying water to escape and then capturing the sediments in a polybottle for later laboratory analyses. Core length was compared with sediment depths measured with the metal rod (see above) at the same location.
Sediment characteristics are known to change with increasing depth (Munsiri et al. 1995); the surface (S) layer is often more prone to resuspension and may have greater water content, than the mature (M) layer below. Thus, any failure to capture the entire sediment profile (reach the original pond bottom) could lead to inaccurate estimates of $\mathrm{dBD}, \%$ sand, and $\mathrm{OM}$ as a percentage of dry mass $\left(\% \mathrm{OM}_{\mathrm{m}}\right)$, owing to the excessive proportional representation of the $\mathrm{S}$ sediment layer. For example, assuming a dBD of $0.3 \mathrm{~g}$ $\mathrm{cm}^{-3}\left(18.7 \mathrm{lb} \mathrm{ft}^{-3}\right)$ within the S-layer of $10 \mathrm{~cm}$ (3.9 in) thickness, a mean $\mathrm{dBD}$ of $0.5 \mathrm{~g} \mathrm{~cm}^{-3}$ $\left(31.2 \mathrm{lb} \mathrm{ft}^{-3}\right)$ within the M-layer beneath, and a restriction of a core to the top $20 \mathrm{~cm}(7.9$ in) of a $30 \mathrm{~cm}$ (11.8 in) sediment profile, the calculated $\mathrm{dBD}$ would be $0.4 \mathrm{~g} \mathrm{~cm}^{-3}$ (25.0 $\mathrm{lb} \mathrm{ft}^{-3}$ ), underestimating the actual $\mathrm{dBD}$ of $0.43 \mathrm{~g} \mathrm{~cm}^{-3}\left(26.8 \mathrm{lb} \mathrm{ft}^{-3}\right)$ by $7.0 \%$. Greater differentiation in $\mathrm{dBD}$ between the layers, or a smaller percentage capture of the total sediment depth in the core sample, would increase the extent of the error, whereas the presence of a thinner S-layer would reduce the impact of incomplete sampling.

Sediment Characteristics. Sediment core samples were fully mixed and then subsampled for analysis of $\mathrm{dBD}, \%$ sand, and OM content. Dry bulk density was determined as mass per volume $\left(\mathrm{g} \mathrm{cm}^{-3}\right)$ following drying of a known volume to constant mass at $105^{\circ} \mathrm{C}\left(221^{\circ} \mathrm{F}\right)$ (Horppila and Niemistö 2008). Percentage of sand was determined as the fraction retained using a $0.06 \mathrm{~mm}$ sieve, oven dried $\left(105^{\circ} \mathrm{C}\left[221^{\circ} \mathrm{F}\right]\right)$, weighed, and expressed relative to total dry mass.

OM content was expressed in two ways. First, $\% \mathrm{OM}_{\mathrm{m}}$ was determined as loss-onignition. The subsamples were crushed using a mortar and pestle (Heal et al. 2006) and combusted at $550^{\circ} \mathrm{C}\left(1,022^{\circ} \mathrm{F}\right)$ for 2.5 hours, following Shuman (2003). Second, organic content was reexpressed per unit sediment volume in each core $\left(\mathrm{OM}_{\mathrm{v}}[\mathrm{mg}\right.$ $\left.\left.\mathrm{cm}^{-3}\right]=\% \mathrm{OM}_{\mathrm{m}} \times \mathrm{dBD}\right)$ following Dean and Gorham (1998).

Sediment Accumulation Rates. Two variables were chosen to describe differences in the quantity of total accumulated sediment among ponds: sediment volume $\left(\mathrm{m}^{3}\right)$ and total OM burial $(\mathrm{kg})$. Organic storage was computed by first multiplying sediment volume by $\mathrm{OM}_{\mathrm{v}}$.

Sediment volume was first divided by pond age and then further divided by pond area to determine sediment accumulation rates per area of pond $\left(\mathrm{SAR}_{\mathrm{p}}\right)$ following Downing et al. (2008). Similarly, dividing annual accumulation rates by watershed area $\left(\mathrm{SAR}_{\mathrm{w}}\right)$ provided estimates of sediment delivery rates per watershed area (Verstraeten and Poesen 2002a).

Annual rates of OM burial per unit pond area $\left(\mathrm{OMB}_{\mathrm{p}}\right)$ were computed by first dividing organic storage by pond age and then by pond area and dividing annual rates of OM burial by catchment area $\left(\mathrm{OMB}_{\mathrm{w}}\right)$.

Finally, vertical accumulation rate (VAR $\left.\left[\mathrm{cm}^{-1}\right]\right)$ was determined at all core and probe locations. Mean VAR for each pond was calculated by averaging the core and probe estimates.

Statistical Analysis. Data were analyzed using SPSS (version 17.0), with significance set at $\mathrm{p}<0.05$. Analyses are grouped below for evaluating (a) variation in sediment characteristics within ponds, and (b) variation in sediment volume and OM accumulation rates among ponds.

Dry bulk density was related to $\% \mathrm{OM}_{\mathrm{m}}$ using the function $\mathrm{dBD}=\mathrm{a}\left(\% \mathrm{OM}_{\mathrm{m}}\right)^{\mathrm{b}}$, following Dean and Gorham (1998). Separate analyses of covariance (ANCOVA) were then performed to determine effects of pond identity (included as a random factor and primarily representing catchment influences on sediment characteristics) and distance from shore (included as a covariate) on the three dependent variables: $\mathrm{dBD}, \%$ sand, and $\% \mathrm{OM}_{\mathrm{m}}$. Significance was evaluated using Type III sums of squares.

Variation in $\mathrm{OM}_{\mathrm{v}}$ was related to VAR (considered as a covariate) and the presence/ absence of a stream inflow using a nested ANCOVA model. Pond identity was nested within the presence/absence of an inflow.

Among-pond differences in sediment accumulation rate and OM storage per unit pond area $\left(\mathrm{SAR}_{\mathrm{p}}\right.$ and $\left.\mathrm{OMB}_{\mathrm{p}}\right)$ were also evaluated using ANCOVA, with pond area considered as a covariate and the presence/ absence of a stream inflow included as a fixed factor in each model. Likewise, differences in sediment and OM delivery per unit catchment area $\left(\mathrm{SAR}_{\mathrm{w}}\right.$ and $\left.\mathrm{OMB}_{\mathrm{w}}\right)$ were evaluated using ANCOVA, with catchment area as a covariate and presence/absence of a stream inflow as a fixed factor.

\section{Results and Discussion}

Seven of the 10 ponds were classified as farm ponds based on current surrounding land use; 3 were considered residential (table 1). Ages varied from 21 to 60 years at the 
Table 1

Morphometric and watershed characteristics of the 10 ponds, classified as farm (F) or residential (R) ponds based on surrounding land use: current pond area $\left(A_{p}\right)$ and catchment area $\left(A_{w}\right)$, the presence/absence of a stream inflow, age at the time of sampling in 2009, current volume and mean depth (MD), the average total sediment thickness at core locations (the average percentage recovery of the 10 cores in parentheses*), the percentage of the original pond volume (assuming no change in water level over time) filled in with sediment (\% FI), and the vertical accumulation rate (VAR).

\begin{tabular}{|c|c|c|c|c|c|c|c|c|c|c|}
\hline $\begin{array}{l}\text { Pond } \\
\text { ID }\end{array}$ & $\begin{array}{l}\text { Pond } \\
\text { type }\end{array}$ & $\begin{array}{l}A_{p} \\
\text { (ha) }\end{array}$ & $\begin{array}{l}A_{w} \\
\text { (ha) }\end{array}$ & $\begin{array}{l}\text { Inflow } \\
(\mathrm{Y} / \mathrm{N})\end{array}$ & $\begin{array}{l}\text { Age } \\
\text { (y) }\end{array}$ & $\begin{array}{l}\text { Volume } \\
\left(\mathrm{m}^{3}\right)\end{array}$ & $\begin{array}{l}\text { MD } \\
(\mathrm{m}) \\
\end{array}$ & $\begin{array}{l}\text { Sediment } \\
\text { thickness } \\
\text { (cm) }\end{array}$ & $\% \mathbf{F I}$ & 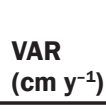 \\
\hline $\mathrm{CU}$ & $\mathrm{R}$ & 0.34 & 27.3 & Y & 42 & 2,817 & 0.82 & $63.4(45 \%)$ & 39.0 & 1.51 \\
\hline EF & $\mathrm{R}$ & 0.39 & 16.2 & $\mathrm{~N}$ & 56 & 4,068 & 1.03 & 30.3 (71\%) & 16.8 & 0.54 \\
\hline GA & $\mathrm{F}$ & 0.50 & 5.9 & $\mathrm{~N}$ & 60 & 3,514 & 0.70 & $43.1(70 \%)$ & 31.3 & 0.72 \\
\hline HE & $\mathrm{F}$ & 0.26 & 13.0 & Y & 25 & 2,165 & 0.84 & $45.6(55 \%)$ & 31.1 & 1.82 \\
\hline KA & $\mathrm{R}$ & 0.05 & 16.5 & Y & 44 & 366 & 0.81 & $133.2(21 \%)$ & 53.4 & 3.03 \\
\hline LY & $\mathrm{F}$ & 0.18 & 10.5 & $\mathrm{~N}$ & 22 & 1,591 & 0.89 & $33.4(72 \%)$ & 20.2 & 1.52 \\
\hline MC & $\mathrm{F}$ & 0.53 & 47.2 & Y & 46 & 5,620 & 1.07 & $58.6(39 \%)$ & 28.8 & 1.28 \\
\hline MO & $\mathrm{F}$ & 0.24 & 17.3 & Y & 48 & 1,456 & 0.62 & 72.8 (31\%) & 46.2 & 1.52 \\
\hline OD & $\mathrm{F}$ & 0.21 & 14.8 & $\mathrm{~N}$ & 21 & 1,406 & 0.68 & 43.5 (49\%) & 30.4 & 2.07 \\
\hline SC & $\mathrm{F}$ & 0.53 & 1.8 & $\mathrm{~N}$ & 42 & 6,181 & 1.17 & 32.5 (61\%) & 14.3 & 0.77 \\
\hline
\end{tabular}

* Percentage recovery of the total sediment thickness at core locations within a pond deviated from $100 \%$ due to the length of the coring device used. The impacts of incomplete capture of the total sediment depth are highlighted in "Field Work and Geographic Information System Analysis."

time of sampling. Pond areas (A) varied by approximately an order of magnitude, from 0.05 to 0.5 ha $(0.12$ to $1.2 \mathrm{ac})$; catchment area also varied widely (2 to 47 ha [5 to 116 ac]) and was uncorrelated with pond area $(r=-0.02)$. Mean depths ranged from 0.6 to $1.2 \mathrm{~m}(1.97$ to $3.9 \mathrm{ft})$. The portion of original water volume occupied by sediments varied from $14 \%$ to $53 \%$ at the time of sampling.

Variation in Sediment Characteristics within Ponds. Results of the ANCOVA model used to evaluate effects of pond morphology on each of the three sediment characteristics are shown in table 2 . With increasing distance from shore, dBD and $\%$ sand decreased, whereas $\% \mathrm{OM}_{\mathrm{m}}$ increased. The random factor "pond" significantly affected sediment characteristics in all ANCOVA models, indicating that other pond attributes, presumably related to their catchment features, accounted for a substantial portion of total variation in sediment characteristics.

The three variables used to describe sediment content ( $\mathrm{dBD}, \%$ sand, and $\% \mathrm{OM}_{\mathrm{m}}$ ) were all intercorrelated $(p<0.001)$. Dry bulk density and $\% \mathrm{OM}_{\mathrm{m}}$ were inversely related (figure 2a), as also shown in previous work (Menounos 1997; Dean and Gorham 1998). As shown by Dean and Gorham (1998), because $\mathrm{dBD}$ and $\% \mathrm{OM}_{\mathrm{m}}$ are inversely related (the exponent in the equation $\mathrm{dBD}=$ $4.27\left(\% \mathrm{OM}_{\mathrm{m}}\right)^{-1.084}$ was very nearly -1 in our study), multiplying $\% \mathrm{OM}_{\mathrm{m}}$ by $\mathrm{dBD}$ may produce surprisingly consistent estimates of $\mathrm{OM}$ expressed per unit sediment volume $\left(\mathrm{OM}_{\mathrm{v}}\right.$

Table 2

Effects of distance from shore (DFS) and the random factor "pond" on variation in sediment characteristics (dry bulk density [dBD], sand content [\% sand], and organic content [\%OM within ponds, based on ANCOVA. Organic content was arcsine transformed prior to analysis. Significant $p$-values are shown in bold.

\begin{tabular}{llllrr}
\hline $\begin{array}{l}\text { Dependent } \\
\text { variable }\end{array}$ & $\begin{array}{l}\text { Independent } \\
\text { variable }\end{array}$ & $\begin{array}{l}\text { Type III } \\
\text { SS }\end{array}$ & Df & \multicolumn{1}{c}{ F } & \multicolumn{1}{c}{$\boldsymbol{p}$} \\
\hline $\mathrm{dBD}$ & DFS & 0.11 & 1 & 5.51 & $\mathbf{0 . 0 2 1}$ \\
& Pond & 0.54 & 9 & 3.01 & $\mathbf{0 . 0 0 4}$ \\
\%OM $_{\mathrm{m}}$ & DFS & 0.02 & 1 & 6.63 & $\mathbf{0 . 0 1 2}$ \\
& Pond & 0.06 & 9 & 2.55 & $\mathbf{0 . 0 1 2}$ \\
$\%$ sand & DFS & 0.46 & 1 & 14.80 & $<\mathbf{0 . 0 0 1}$ \\
& Pond & 1.39 & 9 & 4.94 & $<\mathbf{0 . 0 0 1}$ \\
\hline
\end{tabular}

Notes: Type III SS = Type III sums of squares. $\mathrm{Df}=$ degrees of freedom. $\mathrm{F}=$ F-test statistic.

\section{Table 3}

Nested ANOVA analysis, with organic content (expressed per unit sediment volume) as the dependent variable, vertical accumulation rate $\left(\mathrm{cm} \mathrm{y}^{-1}\right)$ as a covariate, and "pond" nested within the fixed factor inflow. Significant $p$-values are shown in bold.

\begin{tabular}{llrrrr}
\hline $\begin{array}{l}\text { Dependent } \\
\text { Variable }\end{array}$ & $\begin{array}{l}\text { Independent } \\
\text { Variable }\end{array}$ & \multicolumn{1}{l}{$\begin{array}{l}\text { Type III } \\
\text { SS }\end{array}$} & \multicolumn{1}{c}{ Df } & \multicolumn{1}{c}{ F } & \multicolumn{1}{c}{$\boldsymbol{p}$} \\
\hline $\mathrm{OM}_{\mathrm{v}}$ & VAR & 41.46 & 1 & 1.62 & 0.206 \\
& Inflow & $2,585.50$ & 1 & 16.22 & $\mathbf{0 . 0 0 3}$ \\
& Pond (Inflow) & $1,552.70$ & 8 & 7.59 & $<\mathbf{0 . 0 0 1}$ \\
\hline
\end{tabular}

Notes: Type III SS = Type III sums of squares. Df = degrees of freedom. F = F-test statistic.

$\left.\left[\mathrm{mg} \mathrm{cm} \mathrm{cm}^{-3}\right]\right)$. Organic matter content of the cores was significantly greater in ponds with stream inflows $(p=0.003)$ but was unaffected by vertical accumulation rate at the core location (figure $2 \mathrm{~b}$, table 3 ).

Although the relationship of $\mathrm{dBD}$ to $\% \mathrm{OM}_{\mathrm{m}}$ (figure $2 \mathrm{a}$ ) and the evaluation of
OM (figure $2 b$ ) both show clear separation of cores from ponds with vs. without stream inflows, the reasons for the patterns are much less clear. Part of the explanation may involve the ability of streams to transport larger particles to ponds than overland flow or the tendency of ponds with inflows to selec- 


\section{Figure 2}

(a) Curvi-linear relationship between dry bulk density $\left(\mathrm{dBD}\left[\mathrm{g} \mathrm{cm}^{-3}\right]\right)$ and organic content (expressed as percentage of dry mass). $\mathrm{dBD}=4.266\left(\% \mathrm{OM}_{\mathrm{m}}\right)^{-1.084}$. (b) Relationship of organic content $\left(\mathrm{OM}_{\mathrm{v}}\left[\mathrm{mg} \mathrm{cm}^{-3}\right]\right)$ to vertical accumulation rate (VAR) in cores from ponds with inflows (open circles) and ponds without inflows (closed circles). Inflow $=40.46+1.16$ (VAR) and no inflow $=27.4+2.35$ (VAR).

(a)

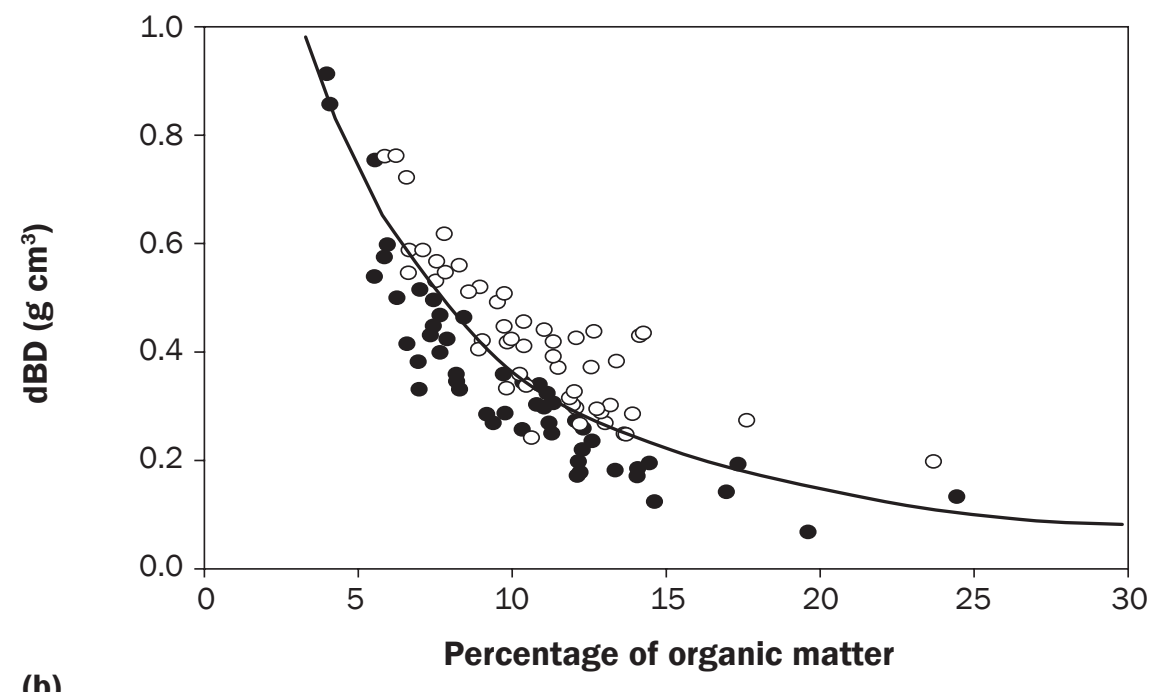

(b)

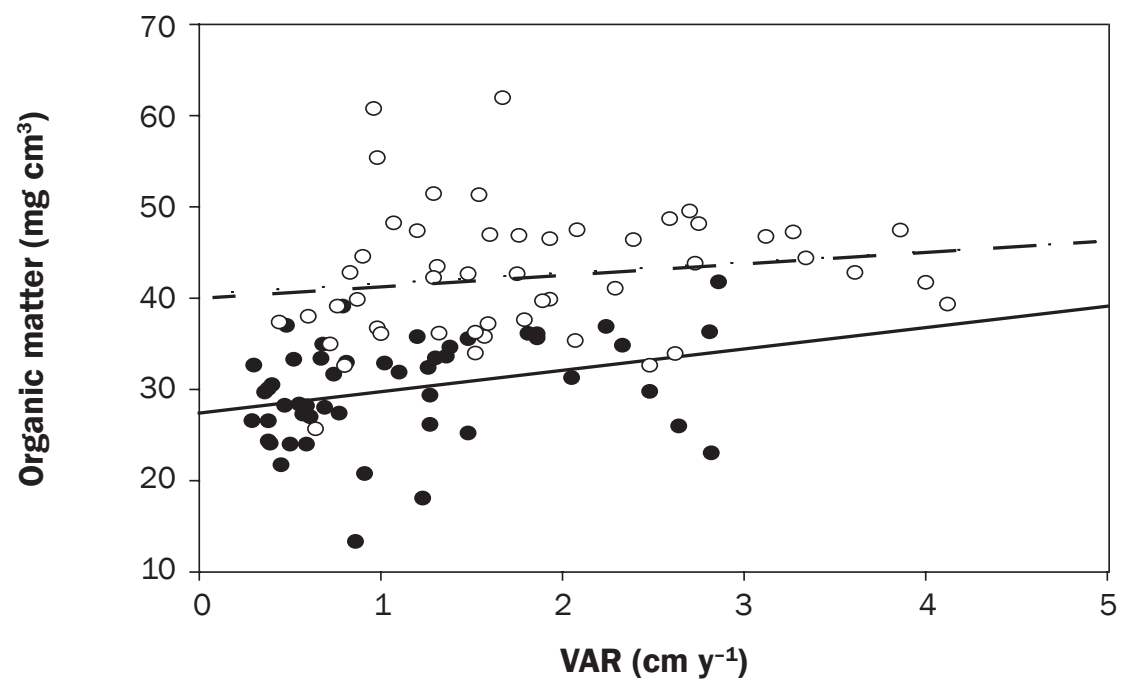

Legend

- No inflow

○ Inflow

tively export smaller particles from ponds via the outfall during precipitation events, thereby elevating dBD. Alternatively, stream inflows may increase OM either by supplying additional refractory organic material of terrestrial origin (Cole et al.2007) or by augmenting nutrient concentrations and thus boosting production by algae and aquatic plants. Impacts of streams on rates of OM burial rates are considered below.
Variation in Sediment Accumulation Rates among Ponds. Sediment accumulation rates, when expressed per unit pond area $\left(\mathrm{SAR}_{\mathrm{p}}\right)$, declined with increasing pond size (figure 3), indicating that large ponds accumulated less sediment per unit area than small ponds $(F=19.634 ; p=0.003)$, and were significantly greater in ponds with stream inflows $(F=7.488 ; p=0.029)$. These two independent variables together accounted for $83.6 \%$ of variation in SAR. Because ponds with inflows typically had larger watersheds (mean $\mathrm{A}_{\mathrm{w}}=24.3$ ha $\left.[60 \mathrm{ac}]\right)$ than ponds without inflows (mean $A_{w}=9.8$ ha $[24.2 \mathrm{ac}]$ ), there was concern that watershed area rather than stream inflow per se might be the cause of elevated SAR values. However, $A_{w}$ did not significantly affect SAR when added to the ANCOVA model ( $p=0.87)$ or when related directly to SAR using simple linear regression $(p=0.62)$ based on this admittedly small dataset. Both pond area and the presence/absence of a stream inflow are relatively easily determined using existing GIS data layers, making it possible to infer aggregate sediment retention by many ponds at the landscape level.

One important result of greater sediment accumulation rates in ponds with influent streams is the likely increased pond management costs they require and a decline in lifespan (Boothby and Hull 1997; Downing 2010). Pond owners rarely plan for the eventuality of sediment in-filling and are often poorly prepared to shoulder the financial costs of dredging when it becomes necessary. Ponds are often drained and replaced with other land uses as a consequence (Hull 1997).

Sediment yields, expressed as accumulation per unit watershed area, decreased with increasing catchment size $(F=12.819 ; p=$ 0.009). Our data are compared with estimates of watershed-specific accumulation rates in ponds by Hayes-Bohanan (1989) and Verstraeten and Poesen (2002a) in figure 4. Hayes-Bohanan (1989) studied the sediment capture by 32 ponds within the larger watershed of Miami Whitewater Lake, Hamilton County, Ohio; the catchments of many of these ponds were smaller than those of the present study and consisted largely of residential, pasture, and wooded land. The 21 ponds summarized by Verstraeten and Poesen (2002a) typically had larger catchments than in the present study; pond areas and landuse data were not provided. Taken together, the three studies support the view that the decline in watershed-specific sediment accumulation with increasing catchment area in larger lakes and reservoirs (Downing et al. 2008) is also observed in small ponds.

Burial rates of OM per unit pond area in this study, like overall sediment accumulation rates, declined with increasing pond area (figure 5a; table 4); likewise, OM burial per unit catchment area decreased with increasing catchment size (figure 5b; table 4). Because 


\section{Figure 3}

Relationship between pond area-specific volume sediment accumulation rate (SARP) and pond area. Ponds with inflows are shown with open circles (dashed regression line), and isolated ponds are represented by closed circles (solid regression line). SAR PINFLOW $_{\text {W }}=$ 202.401-227.212 (Area); SAR P No INFLow $158.9-228.725$ (Area).

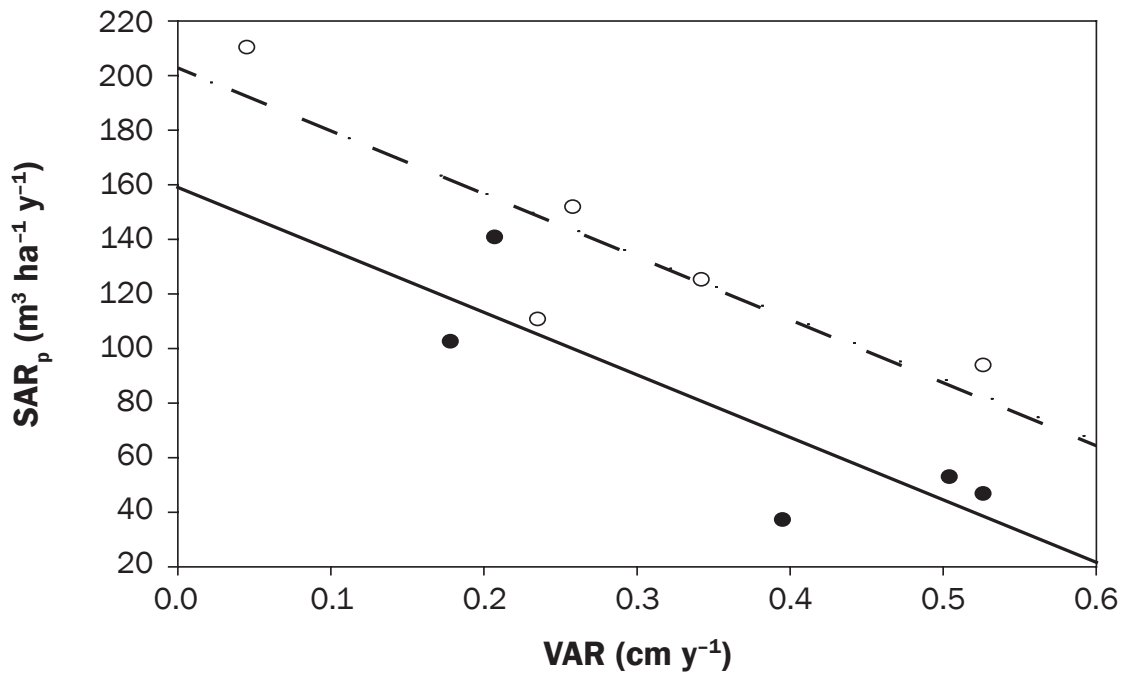

\section{Legend}

- No inflow O Inflow

\section{Figure 4}

Comparison of watershed area-specific sediment volume accumulation rates $\left(\mathrm{SAR}_{\mathrm{w}}\right)$ in 10 ponds (current study) with water bodies studied by Hayes-Bohanan (1989) and Verstraeten and Poesen (2002a). $\log _{10}\left(\mathrm{SAR}_{\mathrm{w}}\right)=1.087-0.407 \log _{10}($ Watershed Size $) ; p<0.001,\left(r^{2}=0.603\right)$.

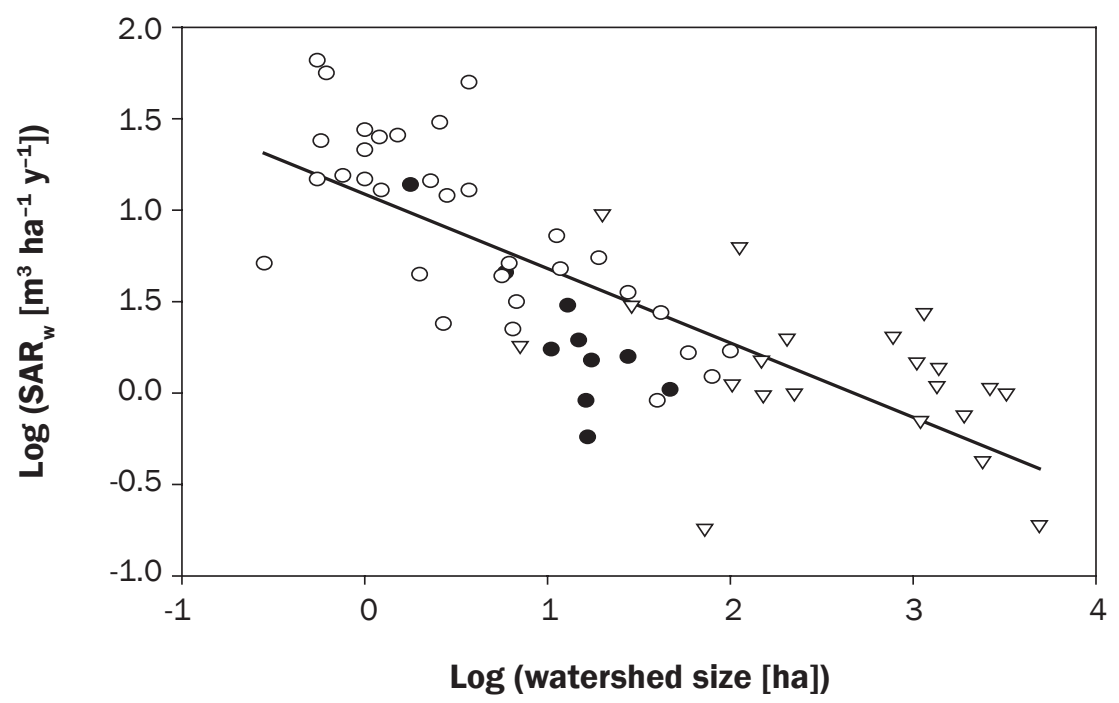

Legend

- Brandywine Ponds $\quad$ O Hayes-Bohanan (1989) $\quad \nabla$ Verstraeten and Poesen (2002a)

freshwaters are increasingly understood to be important organic carbon sinks (Tranvik et al. 2009) and because the number of studies describing carbon burial in ponds remains small, estimates of OM contained in the pond sediments studied here are extrapolated to estimate rates of organic carbon (OC) burial. Although OC was not measured directly, it is sometimes assumed to be a fixed proportion of OM; OC burial in the 10 ponds is compared to previous studies summarized by Downing et al. (2008), using their estimate of $\mathrm{OC} \div \mathrm{OM}=0.47$. The decline in the $\mathrm{OC} / \mathrm{m}^{2}$ ratio with increasing pond area in this study is consistent with similar declines in previously cited work; when extended to the present size range of 0.05 to 0.5 ha $(0.12$ to $1.2 \mathrm{ac}$ ), the ponds most closely resembled predictions for eutrophic water bodies but experienced much lower burial rates than in the 40 agricultural impoundments studied by Downing et al. (2008).

Ponds accumulate sediments at varying rates that can be related to sediment yield within their catchments. Sediment sampling in ponds of known age can provide a useful, low-cost alternative to other approaches (e.g., hydrologic modeling or automated measurements of suspended solids) for estimating sediment loading to streams. Procedural details and caveats associated with the use of ponds to monitor sediment delivery rates in small catchments are provided in a series of papers by Verstraeten and Poesen (2001, 2002a, 2002b).

\section{Summary and Conclusions}

Constructed ponds are increasingly sequestering sediments with associated OM in many regions but, perhaps because of their small size, have received little research attention. This study evaluates the effects of pond morphology on sediment characteristics known to influence the distribution of pond organisms and estimates the influence of pond and local catchment features on sediment accumulation rates.

We found that OM sequestration, whether expressed as concentrations within the sediments or as annual burial rates, was significantly elevated in ponds that were connected to headwater streams. Area-specific sediment accumulation rates increased with decreasing pond size, emphasizing the need to include small water bodies in future research.

As expected from studies of larger systems, the presence of a stream inflow was shown 


\section{Figure 5}

(a) Relationship between pond area-specific organic matter accumulation $\left(\mathrm{OMB}_{\mathrm{p}}\right)$ and pond area. Inflow ponds are represented with open circles (dashed regression line) and isolated ponds by closed circles (solid regression line). $O \mathrm{MB}_{\text {PINFLow }}=9,608.1-11,935.8$ (Area); $p=0.017\left(r^{2}=0.887\right)$. OMB ${ }_{\text {P NO INFLOW }}=5,723.6-8,326.4$ (Area); $p=0.154\left(r^{2}=0.545\right)$. (b) Relationship between watershed area-specific organic matter accumulation $\left(\mathrm{OMB}_{\mathrm{w}}\right)$ and watershed area. Inflow ponds are represented with open circles and isolated ponds by closed circles. $\log _{10}\left(\mathrm{OMB}_{\mathrm{w}}\right)=2.87-0.79 \log _{10}($ Watershed $) ; p=0.006\left(r^{2}=0.629\right)$.

\section{(a)}

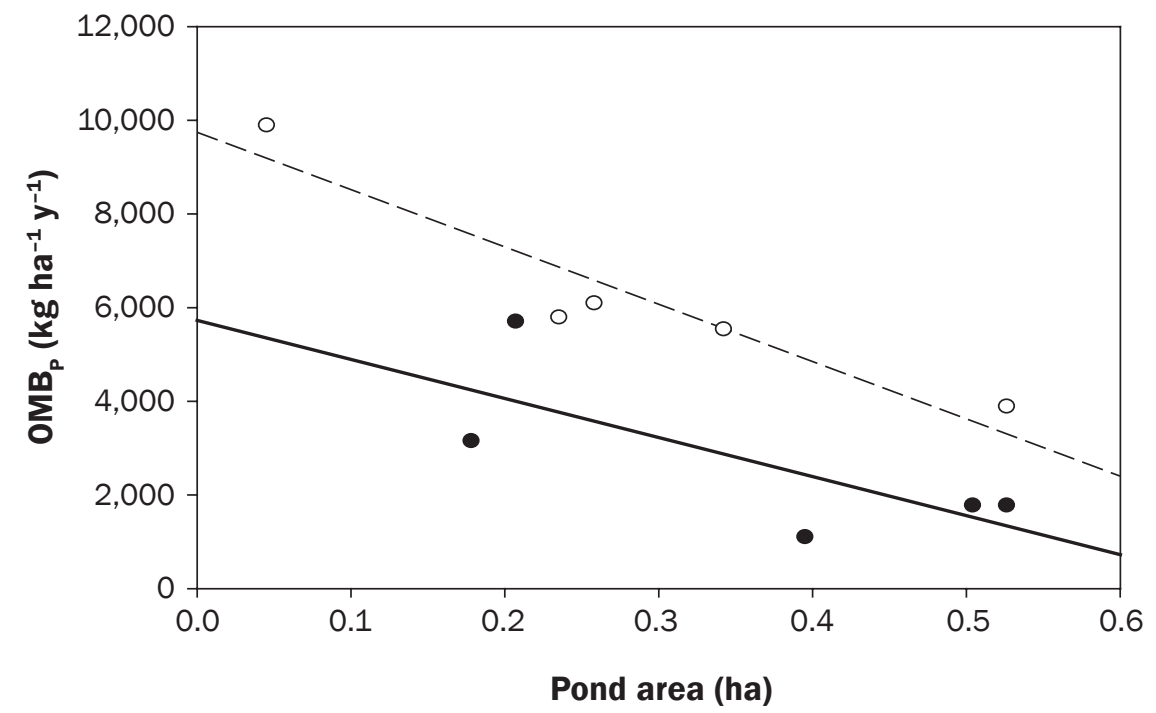

(b)

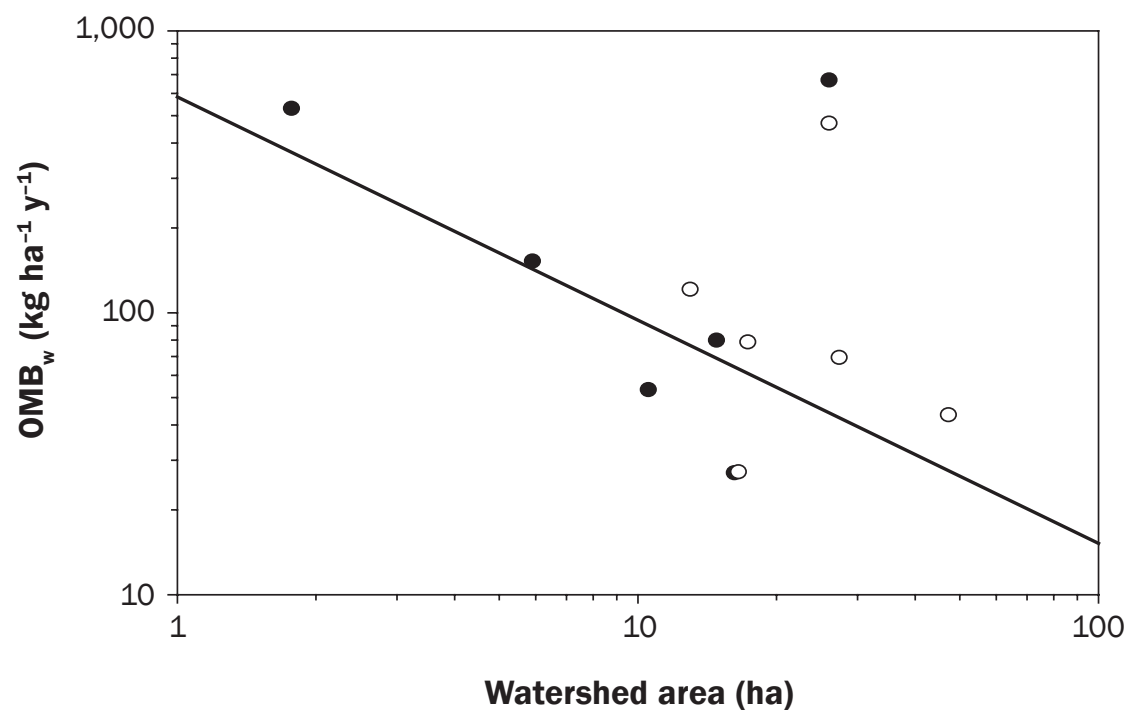

\section{Legend}

- No inflow o Inflow

to increase sediment accumulation and thus reduce pond longevity, an important consideration for landowners, watershed managers, and conservation organizations. Because pond size and the presence/ absence of an inflow together accounted for
Finally, sediment accumulation within ponds may be an accurate alternative to sediment export modeling as a means of estimating sediment delivery to streams. This study thus highlights the role of ponds in both assessing and reducing sediment impairment of stream habitats.

\section{References}

Bert, W., M. Messiaen, F. Hendrickx, J. Manhout, T. de Bie, and G. Borgonie. 2007. Nematode communities of small farmland ponds. Hydrobiologia 583:91-105.

Biggs, J., P. Williams, P.N. Whitfield, and A. Weatherby. 2005. 15 years of pond assessment in Britain: Results and lessons learned from the work of Pond Conservation. Aquatic Conservation: Marine and Freshwater Ecosystems 15:693-714.

Boothby, J., and A.P. Hull. 1997. A census of ponds in Cheshire, North West England. Aquatic Conservation: Marine and Freshwater Ecosystems 7:75-79.

Cole, J.J., T. Prairie, N.F. Caraco, W.H. McDowell, L.J.Tranvik, R.G. Striegl, C.M. Duarte, P. Kortelainen, J.A. Downing, J. Middleburg, and J. Melack. 2007. Plumbing the global carbon cycle: Integrating inland waters into the terrestrial carbon budget. Ecosystems 10:171-184.

Dean, W.E., and E. Gorham. 1998. Magnitude and significance of carbon burial in lakes, reservoirs, and peatlands. Geology 26:535-538.

DeClerck, S., J.Vandekerkhove, L.Johansson, K. Muylaert,J.M. Conde-Porcuna, K. Van der Gucht, C. Perez-Martinez, T. Lauridsen, K. Schwenk, G. Zwart, W. Rommens, J. Lopez-Ramos, E. Jeppesen, W.Vyverman, L. Brendonck, and L. De Meester. 2005. Multi-group biodiversity in shallow lakes along gradients of phosphorus and water plant cover. Ecology 86:1905-1915.

de Vente, J., J. Poesen, M. Arabkhedri, and G. Verstraeten. 2007. The sediment delivery problem revisited. Progress in Physical Geography 31:155-178.

Downing, J.A. 2010. Emerging global role of small lakes and ponds: Little things mean a lot. Limnetica 29(1):9-24.

Downing, J.A., Y.T. Prairie, J.J. Cole, C.M. Duarte, L.J. Tranvik, R.G. Striegl, W.H. McDowell, P. Kortelainen, N.F. Caraco, J.M. Melack, and J. Middleburg. 2006. The global abundance and size distribution of lakes, ponds, and impoundments. Limnology and Oceanography 51:2388-2397.

Downing,J.A.,Y.T. Prairie, J.J. Cole, C.M. Duarte, L.J.Tranvik, R.G.Striegl,andW.H.McDowell.2008.Sediment organic carbon burial in agriculturally eutrophic impoundments over the last century. Global Biogeochemistry 22, GB1018, doi:1029/2006GB002854.

Fairchild, G.W., and D.J. Velinsky. 2006. Effects of small ponds on stream water chemistry. Lake and Reservoir Management 22:321-330.

Fairchild, G.W., J.N. Anderson, and D.J. Velinsky. 2005. The trophic state 'chain of relationships' in ponds: Does size matter? Hydrobiologia 539:35-46. 
Table 4

ANCOVA results for pond area-specific organic matter burial $\left(O \mathrm{MB}_{\mathrm{p}}\right)$ and watershed areaspecific organic matter burial $\left(O M B_{w}\right)$ as dependent variables, pond area $\left(A_{p}\right)$ or watershed area $\left(A_{w}\right)$ as covariates, and stream inflow treated as a fixed factor in each model. Significant $p$-values are shown in bold.

\begin{tabular}{llllll}
\hline $\begin{array}{l}\text { Dependent } \\
\text { variable }\end{array}$ & $\begin{array}{l}\text { Independent } \\
\text { variable }\end{array}$ & $\begin{array}{l}\text { Type III } \\
\text { SS }\end{array}$ & Df & F & $\boldsymbol{p}$ \\
\hline $\mathrm{OMB}_{\mathrm{p}}\left(\mathrm{kg} \mathrm{ha}^{-1} \mathrm{y}^{-1}\right)$ & $\mathrm{A}_{\mathrm{p}}(\mathrm{ha})$ & $2.399 \times 10^{7}$ & 1 & 18.492 & $\mathbf{0 . 0 0 4}$ \\
& Inflow & $1.71 \times 10^{7}$ & 1 & 13.234 & $\mathbf{0 . 0 0 8}$ \\
$\mathrm{OMB}_{\mathrm{w}}\left(\mathrm{kg} \mathrm{ha}^{-1} \mathrm{y}^{-1}\right)$ & $\mathrm{A}_{\mathrm{w}}$ (ha) & 0.802 & 1 & 13.681 & 0.008 \\
& Inflow & 0.059 & 1 & 1.410 & 0.274 \\
\hline
\end{tabular}

Notes: Type III SS = Type III sums of squares. $\mathrm{Df}=$ degrees of freedom. $\mathrm{F}=$ F-test statistic.
Verstraeten, G., and J. Poesen. 2002b. Regional scale variability in sediment and nutrient delivery from small agricultural watersheds. Journal of Environmental Quality 31:870-879.

Xie, Y., S. An, and B. Wu. 2005. Resource allocation in the submerged plant Vallisneria natans related to sediment type, rather than water-column nutrients. Freshwater Biology 50:391-402.

Walter, R.C., and D.J. Merritts. 2008. Natural streams and the legacy of water-powered mills. Science 319:299-304.
Hayes-Bohanan, J.K. 1989. Source-area erosion rates in areas tributary to Miami Whitewater Lake. Master's thesis, Miami University.

Heal, K.V., D.A. Hepburn, and R.J. Lunn. 2006. Sediment management in sustainable urban drainage system ponds. Water Science and Technology 53:219-227.

Heinemann, H.G. 1981. A new sediment trap efficiency curve for small reservoirs. Journal of the American Water Resources Association 17:825-830.

Horppila, J., and J. Niemisto. 2008. Horizontal and vertical variations in sedimentation and resuspension rates in a stratifying lake - Effects of internal seiches. Sedimentology 55:1135-1144.

Hull, A. 1997. The Pond Life Project: A model for conservation and sustainability. In British Pond Landscapes, ed. J. Boothby, 101-109. Proceedings of the UK Conference of the Pond Life Project held at University College, Chester September 7-9, 1997.

Jackson, C.R., and C.M. Pringle. 2010. Ecological benefits of reduced hydrologic connectivity in intensively developed landscapes. Bioscience 60:37-46.

Madsen, J.D., P.A. Chambers, W.F. James, E.W. Koch, and D.F. Westlake. 2001. The interaction between water movement, sediment dynamics, and submersed macrophytes. Hydrobiologia 444:71-84.

Maxted, J.R., C.H. McCready, and M.R. Scarsbrook. 2005. Effects of small ponds on stream water quality and macroinvertebrate communities. New Zealand Journal of Marine and Freshwater Research 39:1069-1084.

Menounos, B. 1997. The water content of lake sediments and its relationship to other physical parameters: An alpine case study. The Holocene 7:207-212.

Mielke, L.N. 1985. Performance of water and sediment control basins in northeastern Nebraska. Journal of Soil and Water Conservation 40:524-528.

Munsiri, P., C.E. Boyd, and B.F. Hajek. 1995. Physical and chemical characteristics of bottom soil profiles in ponds at Auburn, Alabama, USA, and a proposed system for describing pond soil horizons. Journal of the World Aquaculture Society 26:346-376.

Newman, D.J., D.R. Perault, and T.D. Shahady. 2006. Watershed development and sediment accumulation in a small urban lake. Lake and Reservoir Management 22:303-307.

Oertli, B., J. Biggs, R. Cereghino, P. Grillas, P. Joly, and J.B. Lachavanne. 2005. Conservation and monitoring of pond biodiversity: Introduction. Aquatic Conservation: Marine and Freshwater Ecosystems 15:535-540.

Rausch, D.L., and H.G. Heinemann. 1975. Controlling reservoir trap efficiency. Transactions of the American Society of Agricultural and Biological Engineers 18:1105-1108.

Rausch, D.L., and J.D. Schreiber. 1981. Sediment and nutrient trap efficiency of a small flood-detention reservoir. Journal of Environmental Quality 10(3):288-293.

Renwick, W.H., K.J. Carlson, and J.K. Hayes-Bohanan. 2005. Trends in recent reservoir sedimentation rates in Southwestern Ohio. Journal of Soil and Water Conservation 60:72-79.

Santucci,V.J., S.R. Gephard, and S.M. Pescitelli. 2005. Effects of multiple low-head dams on fish, macroinvertebrates, habitat, and water quality in the Fox River, Illinois. North American Journal of Fisheries Management 25:975-992.

Shuman, B. 2003. Controls on loss-on-ignition variation in cores from two shallow lakes in the northeastern United States. Journal of Paleolimnology 30:371-385

Smith, S.V.,W.H. Renwick, J.D. Bartley, and R.W. Buddemeier. 2002. Distribution and significance of small, artificial water bodies across the United States landscape. The Science of the Total Environment 299:21-36.

Sondergaard, M., E. Jeppesen, and J.P. Jensen. 2005. Pond or lake: Does it make any difference? Archiv für Hydrobiologie 162:143-165.

Tiner, R. 1989. Current status and recent trends in Pennsylvania's wetlands. In Wetlands Ecology and Conservation: Emphasis in Pennsylvania, ed. S.K. Majumdar, 368-378. Easton, PA: The Pennsylvania Academy of Science Publications.

Tranvik, L.J., J.A. Downing, J.B. Cotner, S.A. Loiselle, G. Striegl, T.J. Ballatore, and G.A. Weyhenmeyer. 2009. Lakes and reservoirs as regulators of carbon cycling and climate. Limnology and Oceanography 54:2298-2314. Verstraeten, G., and J. Poesen. 2001. The importance of sediment characteristics and trap efficiency in assessing sediment yield using retention ponds. Physics and Chemistry of the Earth (B) 26:83-87.

Verstraeten, G., and J. Poesen. 2002a. Using sediment deposits in small ponds to quantify sediment yield from small catchments: Possibilities and limitations. Earth Surface Processes and Landforms 27:1425-1439. 